\title{
Domov jako dimenze lidského života v prózách Viktora Astafjeva
}

\section{Home as a Dimension of Human Life in the Prose Works of Victor Astafyev}

Zdeňka Matyušová

(České Budějovice, Česká republika)

\begin{abstract}
Abstrakt:
Předložená stat pojednává o tvorbě ruského spisovatele Viktora Astafjeva (1924-2001), který je výrazným představitelem ruské vesnické prózy. Jeho tvůrčí činnost byla a zůstává pozoruhodným jevem především v literárním procesu 60.-90. let dvacátého století. Svým zaměřením na globální a věčné problémy lidstva, specifickým způsobem a stylem psaní Viktor Astafjev neustále přitahuje zájem a pozornost. Pojednání se soustředuje zejména na motiv domova jako dimenzi lidského života, který je jedním z nejpodstatnějších v celé jeho tvorbě a zejména pak v dílech Hořikvět (1959), Přes peřeje (1960) a Poslední pocta (1957-1978).
\end{abstract}

\section{Klíčová slova:}

Viktor Astafjev; ruská literatura 2. poloviny 2o. století; prozaická tvorba; motiv domova; dimenze lidského života; Hořikvět; Přes peřeje; Poslední pocta

\section{Abstract:}

The presented article deals with the work of the Russian writer Viktor Astafjev (1924-2001), who is a prominent representative of the Russian village prose. His creative activity was and remains a remarkable phenomenon, especially in the literary process of the 1960s and 1990s. With his focus on the global and eternal problems of humanity, the specific way and style of writing, Viktor Astafjev constantly attracts interest and attention. The treatise focuses mainly on the motif of home as a dimension of human life, which is one of the most important in his entire workand especially in the prose The Fireflower (1959), Across the Rapids (1960) and The Last Tribute (1957-1978). 


\section{Key words:}

Victor Astafyev; Russian literature of the second half of the zoth century; home motive; dimension of human life; The Fireflower; Across the Rapids; The Last Tribute

Ruská vesnická či venkovská próza je unikátním fenoménem ruské literatury druhé poloviny dvacátého století. Vzhledem $\mathrm{k}$ omezenému rozsahu našeho pojednání pouze stručně konstatujeme, že jako reakce na společenské procesy ruská literatura o vesnici (obdobně jako literatura polská, česká, slovenská) projevuje v tomto období kvalitativně nové znaky a rysy. Soustavněji si všímá také toho, že ve své době převratné pokrokové změny radikálně urychlují zánik archaického venkovského prostředí s jeho zvláštním viděním světa, hodnotovou hierarchií, mravními normami a kulturou. Próza o vesnici je nepochybně jedním z nejpozoruhodnějších jevů ruské literatury. Na jedné straně zobrazuje a poukazuje na sociální a mentální zvláštnosti venkova, na straně druhé ve specificky vesnických jevech zároveň hledá jakousi univerzální lidskou podstatu. $\mathrm{K}$ jejím nejvýraznějším představitelům patří takoví osobití spisovatelé, jakými jsou B. Možajev, F. Abramov, V.Šukšin, S.Zalygin, V. Solouchin, V. Bělov, J. Nosov, V. Astafjev, V. Rasputin, V. Těndrjakov a mnozí další.

Viktor Astafjev vstupuje do literatury v šedesátých letech dvacátého století. Typickým rysem této etapy realismu je kritický a neúprosný analytismus. Je to určitý signál k rozvoji lyrizované prózy s upozaděným vnějším dějem, která je významnou tradiční linií ruské literatury - I. S. Turgeněv, A. P. Čechov, M. Prišvin, I. Bunin, A. Grin, K. Paustovskij a další. Projevuje se v ní snaha tvưrců spojovat své autorské ,já“ s pocity, prožitky a názory postav. Lyrická forma umožňuje odhalovat nejjemnější záchvěvy a nejskrytější koutky hrdinovy duše, poetizovat svět jeho myšlenek, nahližet do emocionální sféry života, dotýkat se výlučně mravních problémů člověka a vyjádřit svůj vztah k tomu, co se v životě odehrává.

$\mathrm{Na}$ vztah člověka a prrírody je nahlíženo především jako na vztah přirozeného souladu a sounáležitosti. $Z$ té pak následně vyplývá další jistota - jistota domova, která je interpretována v obecně lidské poloze jako pouto k rodnému kraji. Takováto svého druhu reflexivní, vnitřně „zadumaná“ varianta vesnické prózy se objevuje v povídkách a denících J. Kazakova, v črtách V. Solouchina, v povídkách J. Kuranova, S. Nikitina, A. Pristavkina, v novelách Č. Ajtmatova, V. Astafjeva, V. Bělova, J. Nosova a dalších.

Typickým rysem a dominantní vlastností tvorby ruského prozaika Viktora Astafjeva (1924-2001) je její silná duchovní a charakterová zralost, vnitřní působivost, citová sdělnost, realizující se účinností emocionální náplně, která je uložena v každém uměleckém obrazu. Je pro ni typická hluboká motivace pramenící z jeho pohnutého dětství, které se stává citlivým barometrem všech následných událostí. 
„Астафьев обращается к воспоминанию далекой поры детства, итобы восстановить духовную атмосферу того времени, когда проходило первичное становление характеров его сверстников. Нравственный и гражданский фундамент закладывается именно в детстве, и тут не второстепенное значение имеет, кто, как говорится, при сем присутствовал. "1

Viktor Astafjev důvěrně zná rodný venkovský kraj a jeho obraznost je jím samotným vypěstována a rozvíjena do obdivuhodné jistoty a mistrovské kultivovanosti. Tato výrazně subjektivní motivace se projevila především v emocionálním zabarvení jeho prozaických děl a je rovněž zdrojem jejich typického lyrického vyznění. Lyrika byla Astafjevovi filozofií a kosmogonií života veškeré civilizace - chtěl postihnout nejenom pouze jeden lidský osud, ale dráhu všeho lidstva uprostřed celého kosmu.

Proces lyrizace, který začal už v Astafjevových raných dílech Hořikvět (orig. Стародуб, 1959, с̌es. 1963) а Přes peřeje (orig. Перевал, 1960, čes. 1963), dosahuje svého vrcholu v knihách Poslední pocta (orig. Последний поклон, 1957-1978, čes. 1963), Pastýr a pastýrka. Moderní pastorále (1967-1971) a fejí Veličenstvo ryba (orig. Царь-рыба, 1972-1975, čes. 1981). Skutečnost, že i po vzniku těchto děl se v drobných, vzpomínkově laděných prózách Záseky (orig. Затёcu, 1961-1988, nepřeloženo) Astafjev vrací do rodných míst, svědčí o síle této subjektivní motivace.

„Astafjev si libuje v lyrickém vyprávění, nabádajícím $k$ zamyšlení, projevujícímu se umělecky i lidsky ve skromné zdrženlivosti“"

Silným pramenem Astafjevova lyrismu je spojení objektivnosti se subjektivností, složitosti, rozpornosti a nesouladu s jednoduchostí, prostotou a harmonií. Je nezpochybnitelné, že určující složkou Astafjevova tvůrčího profilu byla silná emocionalita, která se v něm vyvíjela od raného dětství a zabarvila jeho veškerou tvorbu zřetelným autobiografickým akcentem. Spisovatelova stěžejní díla jsou svérázným deníkem jeho života, obrazem jeho bytosti, přebásněním niterných zážitků a dojmů. Odkrývají velikost a úsilí umělce, jeho lidské nitro, zápas o poznání a kreativitu, odhalují jak lidský faktor, tak i individualitu tvưrce. Astafjev tíhl k věcem zajímavým a zdánlivě obyčejným, které však silně podněcovaly a vzrušovaly jeho obrazotvornost. Hlavními inspiračními zdroji jeho tvorby se staly láska k př́rodě, $\mathrm{k}$ rodnému kraji, vřelý vztah $\mathrm{k}$ zemi a $\mathrm{k}$ lidem, láska $\mathrm{k}$ mamince, $\mathrm{k}$ babičce $\mathrm{a}$ úcta $\mathrm{k}$ ženě vůbec. Na těchto atributech je založen Astafjevi̊v univerzální vztah ke všemu lidskému, k plnosti života, k jeho realitě a mnohotvárnosti.

1 LANŠČIKOV, A. P.: Viktor Astafjev. Moskva: Sovetskaja Rossija, 1975, s. 32.

2 KASACK, W.: Slovník ruské literatury 2o. století. Praha:Votobia, 200o, s. 49. 
„Его творчеству свойственна достоверность [...] суть не в автобиграфичности, а в том, что историческая биография предельно сопряжена с судьбой и духовной биографией писателя. "3

Dokladem určitého kvalitativního zlomu v Astafjevově tvorbě je v osmdesátých letech novela Smutný detektiv / Smutná detektivka (orig. Печальный детектив, 1986, čes. 1988). V tomto období píše také řadu literárně-kritických a publicistických článků. Příklon k publicistice se zřetelně odráží hlavně již ve výše zmíněném sborníku lyricko-filozofických miniatur s názvem Záseky a v cyklech črt Vidoucí berla (orig. Зрячий посох, 1988, nepřeloženo). Mezi několika posledními publikovanými Astafjevovými díly upoutala pozornost povídka Людочка (1987, nepřeloženo), novela Обертон (1996, Новый мир, nepřeloženo) a román Прокляты и убиты (1992-1997, Новый мир, nepřeloženo).

Ve všem, co vytváří jakýsi společný jmenovatel všech zmíněných Astafjevových próz, jejich hlubokou spojitost a jednotu, se odráží sám naturel jejich autora. Viktor Astafjev se projevuje jako prozaik základních všelidských vztahů a citů $\mathrm{k}$ tomu nejbližšímu, co člověk má - $\mathrm{k}$ domovu a jeho prostým věcem, $\mathrm{k}$ matčině bytosti a k rodné zemi. Sibiřské venkovské kořeny obdařují spisovatelovu osobnost jemnou imaginativností, náklonností k ústní lidové slovesnosti, citlivým smyslem pro přírodní atmosféru a obdivuhodným cítěním krajiny. Astafjevův pohled na krajinu není statický, nebot to nedovoluje jeho ustavičný pocit nepřetržitého časového plynutí a nenávratného mizení života. V některých pasážích jeho próz cítíme něco, co bychom mohli označit jako vteřinové zastavení času - zamyšlení, krajinný dojem nebo zasněný pohled přechází vzápětí v předtuchu, něžný cit, laskavou vzpomínku či jemnou barevnou melodii.

„... красивый иветок назвали в честь любимого дерева - дуба [...] Цветок этот сделался постоянный, неумирающий памятью о родном крае [...] Каждую весну зажигались ясным огнем по всей Сибири стародубы и роняли семена, чтобы никогда не переставала цвесть земля, чтобы сердие человека наполнялось духом ее и не истлевала в нем память о том крае, который его родил. “4

Zároveň je Astafjev jako lyrik zahleděn do prrírodního dění a vidí v něm nepochybnou paralelní souměrnost s lidským osudem. Dá se říci, že transformuje a dramatizuje př́rodu lidským osudem a lidský osud př́rodou. Vždy si byl vědom toho, že duchovní dimenze člověka je nejdůležitější. Hledá souvislosti mezi životem člověka a životem prrírody, které přisuzuje zvláštní sílu a schopnost neustále se obnovovat. Astafjev

3 CHVATOV, A. I.: Na rodnoj zemle, v rodnoj literature. Moskva: Sovremennik, 1980, s. 308.

4 ASTAFJJEV, V.P.: Pereval. In: Sobranije sočinenij v četyrjoch tomach. Moskva: Molodaja gvardija, 1979, tom 1, s. 48 . 
vyzývá $\mathrm{k}$ návratu $\mathrm{k}$ nezničitelné přírodě, který se tak stává návratem ke kořenům a zakotvení lidské bytosti.

Ruský literární kritik Alexandr Makarov napsal:

„... о Викторе Астафьеве хочется писать так же раздумчиво, как пишет он сам, словами простыми, таящими в себе и запахи широкошумной тайги, и шорох на Енисее, и строгий покой лесных озер, и звонкую стынь родников [...] Словами меткой и вольной русской речи, которые как бы сами по себе сплетаются в тесный хоровод, являющий яркий образ, способный вызвать глубинный отзвук в вашей душе. ${ }^{\text {"5 }}$

Viktor Astafjev nesl uvnitř v sobě ideu kosmické harmonie, souladu člověka s dalšími lidmi a člověka s přírodou. Uvědomoval si, že odvěká př́rodní vyváženost tvoří na sobě závislé protiklady aktivního a pasivního, rozumového a smyslového, přírodního a lidského. Tyto dialektické vztahy domyslel a dovedl do významových, výrazových a kompozičních důsledků. Astafjev zachytil a vystihl jednotu člověka a země, jejich vzájemnou těsnou propojenost a jeho osobnost se bezprostředně prolnula s výrazem vlastního díla v syntetické jednotě a ucelenosti.

Výjimečným a osobitým dílem, ve kterém Viktor Astafjev nalezl životodárnou studánku, z níž vytryskl pramínek, který protéká celou jeho tvorbou, je próza Poslední pocta - a předtím již také zejména novela Přes peřeje. Tím pramínkem je domov a dětství lyrického hrdiny, dětství, v němž člověk prožívá čas jakoby bezděčně a nevědomě, ale přesto - a možná asi právě proto - se všechny dojmy a prožitky ukládají a fixují v jeho duši hlouběji a předznamenávají životní cestu. Teprve mnohem později další vývoj odhaluje skutečnou podstatu a rovněž u Viktora Astafjeva vyšlo najevo, že jeho lidská a umělecká osobnost má své kořeny $\mathrm{v}$ živé vodě zážitků $\mathrm{z}$ dětství a mládí, $\mathrm{v}$ zážitcích v pravém a plném slova smyslu štastně osudových. Dětství a krajina domova se pro Astafjeva staly silně a mocně prožívanou estetickou hodnotou, která si vyžadovala ekvivalentní umělecké ztvárnění.

Astafjevova próza Poslední pocta je poetickou, ideově neobyčejně bohatou výpovědí o životě. Je dokladem spisovatelovy spolehlivé paměti a umění vracet se zpět do minulosti, působivě ji oživovat a vykreslovat očima vzpomínek. Myšlenková nosnost cyklu spočívá v důrazu na paralelu domov - dětství, v osobitém tvarovém rozmezí symboliky obou motivů, ve zvýraznění poetických a emotivních aspektů jejich vzájemného vztahu.

„... dotváři se obraz idylického dětství u babičky i tragédie matčiny smrti a rodinných zvratů [...] Smrt Petěnky, chlapce v bilé košilce, návštěva fotografa, dětské hry, utopení děda, potulky s kamarády i pobyt v dětském domově vytvářejí podivuhodnou směs lítosti,

5 MAKAROV, A. N.: Vo glubine Rossiji. Moskva:Sovremennik, 1973, s. 277. 
smutku a stesku, radosti a pláče, exotiky a hluboké lidskosti, již se Astafjev dotkl kořenů ruského národního charakteru. "6

Neobyčejně silný motiv domova prorůstá snad všemi Astafjevovými prózami. S ním jsou spojeny rozhodující momenty jeho uměleckého i lidského vyzrávání, radosti i smutky, láska i stesk, hluboké průniky pod povrch života i umění. Pocit domova a návraty $\mathrm{k}$ němu jsou celoživotně spojené s lidským odpuštěním, vyrovnáním a smířením. U Viktora Astafjeva jde o osobitou planetární dimenzi domova. Domov je pro něj jakýmsi prvopočátkem, místem, kam se člověk vrací pro posilu v těžkých chvílích, kdy cítí odpovědnost za stav věcí, pro naději ve chvílích nejtěžších, pro ozvěnu dětství i pro něžnou vzpomínku. Je nevyčerpatelným a nepřetržitým zdrojem tvůrčí inspirace i hřejivým zázemím.

Tento pocit je neoddělitelně spojen a neodmyslitelně provázán s návratem domů, kdy se Astafjevův autobiografický hrdina zasnívá do chvil dětství, doslova prahne po něm samém, dychtí po jeho kouzlu, přestože zároveň zakouší hořce bolestné vědomí jeho nenávratna.

Metaforicky vysloveno, život je cesta, která by vždy měla vést $\mathrm{k}$ jedinému a nezaměnitelnému domovu každého člověka. Snad právě proto Viktor Astafjev tak často vzpomíná na maminku a věnuje tolik pozornosti babičce, která po maminčině kruté smrti ze všech sil pro něj kouzlo domova vytvářela a udržovala až do posledních chvil svého života. Astafjevova vzpomínková obraznost bezprostředně a bezelstně vyvolává jeho citové záchvěvy a stavy, smysl pro jemnou a precizní alchymii vjemů a pocitů.

A Viktoru Astafjevovi umožnil motiv domova sjednotit často rozdílné texty a stal se vedle motivu dětství a přirody základním kompozičním prvkem Poslední pocty, kolem kterého se soustředují jak prózy reflexivní a lyrické, tak i prózy s epickým jádrem. A středobodem všeho je člověk, zasazený pevně do konkrétního prostředí, jeho zrození, cesta životem a smrt.

Lidský osud bývá složitý a, obrazně naznačeno, člověk má jen dvě cesty - jednu na svět a druhou z něho pryč. A mezi tím, ta krátká doba, kdy se ani nestačí pořádně rozhlédnout, leží celý jeho život. A to je mnohdy moc málo. Proto Astafjev oslovuje domov, ve kterém je teprve sám sebou, dávný čas dětství a rodný kraj, které jsou neodmyslitelnou podmínkou jeho lidské existence i tvůrčí inspirace. Jsou to sféry působnosti, v nichž se rozvíjí Astafjevův horoucí, křehký a spontánní lyrismus smyslového okouzlení a citového stesku.

6 POSPÍŠIL, I.: Ruský román znovu navštívený. Historie, uzlové body vývoje, teorie a mezinárodní souvislosti: Od počátků $k$ výhledu do současnosti. Brno: Nadace Universitas: Cerm: Nauma, 2005, s. 106. 
„Нет, яркость астафьевского слова - его призвание, его манера, кстати сказать, манера традиционная, хотя и вечно новая, а для нас - это большое истинное наслаждение."

Výrazný půvab a barvité kouzlo rodné sibiřské krajiny dětství se zrcadlí v prozaikově představivosti odstíněnými postřehy a spletitými dojmy, v nichž se navzájem prolínají zdání a představy rozmanitých smyslových oblastí. Senzitivní, vroucí a hluboký smutek nad umírající babičkou vyznívá v závěrečný rozechvělý žalozpěv odumírajícího lidství a odcházejícího světa.

Disonanční akordy života se snaží překlenout vzpomínkou na ochranitelskou náruč maminčinu a babiččinu, přestože toto nejbližší a nejcitlivější místo jeho nekonečně rozlehlého kosmu zasáhla v obou případech nečekaně krutě smrt. Pohlcen a jakoby zostřen bolestí, vidí svůj osud, nahlas říká, co procítil a promyslel.

„Все, как было - серый бык со ржавчиной на щеках; молодые осинники вроссыпь на склонах гор; изеты, кусты меж каменьев и по распадкам, и все так же катит и кружит водь река. Нет ни тревоги, ни горя, лишь слабый отзвук печали nощципьвает сердие. "8

Bolest nad touto ztrátou nikdy nezmizí z jeho další tvorby a postupně přechází z niterně subjektivního prožitku v apoteózu mateřské lásky jako symbolu nejlidštějšího citu. A navíc je vše provázeno motivem paměti, je možné říci jakési kosmické paměti, nebot' předměty a jevy nejsou pevně a neproniknutelně ohraničeny, neexistují samy o sobě a pro sebe, ale jsou jakoby propojeny s kosmem a jeho nekonečností - je cítit jejich minulý čas a lze vytušit i jejich čas budoucí.

„... все-все вокруг меня и надо много было так утихомиренно, так похоже на прежний, детской памяти, вечер, что я невольно доверился этому ближнему покою, погрузился в него, будто в глубокую, солнцем налитую воду... Ни о чем я не думал, ничто меня больше не тревожило - было так хорошо, так светло на сердие [...] и я смотрел в дырку от сучка, где раз-другой поискрила вечерняя звезда, и хотелось мне, чтоб вечно так было: тепльй дом, деревенская тишина...".

Ze všeho toho, co zde bylo doposud vyřčeno o autorově tvorbě, je evidentní, že jedinečnou dominantou jeho prózy je domov, který má své neměnné konstanty. Je to domov fixovaný v přesné časové posloupnosti, ve vzpomínkových obrazech maminky, babičky, cesty k domovu, stromů, nebe, lesů, polí a v semknutosti s půdou a se zemí, která poskytuje životní jistotu.

„Поэт Пан Юйлян в своём эссе «Земля, слезами политая» пишет:

7 ZALYGIN, S.: Svoje slovo. In: ZALYGIN, S.: Literaturnyje zaboty. Moskva: Sovetskaja Rossija, 1982, S. 236.

8 ASTAFJEV, V.P.: Poslednij poklon. In: Sobranije sočinenij v četyrech tomach. Moskva: Molodaja gvardija, 1980, tom 1, s. 512.

9 Ibidem, s. 527-529. 
«Я знаю, что, следуя за Астафьевым, не заблудишься... а оставленные им затеси светятся, как капли мёда. Те капли, похожие на светлячков, всегда вспльвают перед моими глазами!.. Те затеси вместе с огоньками кажутся такими живыми и добрыми, будто они зовут меня, ведут меня в глубину жизни...». "10

Každá Astafjevova próza je, $v$ přeneseném smyslu slova, jakousi přehlednou křižovatkou jeho vlastní minulosti s okamžiky př́tomnými a událostmi budoucími. Tvůrcův lidský čas je jakoby vpleten do labyrintu dávno prožitých chvil, které jsou nyní už nenávratně uplynulé, zmizelé, ztracené, ale prostřednictvím vzpomínek jsou zároveň životodárně momentální, oživlé, současné.

$Z$ výše uvedeného vyplývá, že Viktoru Astafjevovi je až nevídaně vlastní jakési hledání moudrosti. Nalézáme ho v jeho postoji, jenž hodnoty lidského bytí nazíral prizmatem svého života, návratem $\mathrm{k}$ dětství a $\mathrm{k}$ domovu, $\mathrm{v}$ bázlivé důstojnosti, jíž se vyznačovalo jeho plaché chování a rovněž také v nesmlouvavém odhodlání jít vlastní cestou, byt' v jisté opuštěnosti, ale ve shodě s hlubokou jistotou svého srdce.

„Проза Астафьева [...] это всегда размышление о нашей жизни, о назначении человека на земле и в обществе и его нравственных устоях [...] Астафьев по натуре своей он моралист и поэт человечности и относится $к$ тому роду художников, которые пишут о душе - предмете необъяснимом и как бы иллюзорном, однако всем понятном. "11

Základním symptomem Astafjevova literárního vývoje, v jehož zrcadle zřetelně vidíme uzlové momenty lidského i uměleckého zrání a jádro jeho kreativní osobnosti, je námi již několikrát zmíněný vztah $\mathrm{k}$ domovu jako $\mathrm{k}$ odvěké jistotě člověka. Prozaik vložil do své tvorby sebe samého, svoje mnohdy nepojmenovatelné vzpomínky, záhadné otazníky, fantazii, prožitky, nejistoty i úzkosti, pochopené i nepochopené otázky, úžas a okouzlení nad tajemstvím života i světa, celou hlubinu vlastního vnitřního bytí.

„Его творчеству свойственна достоверность, [...] суть не в автобиографичности, а в том, что историческая биография предельно сопряжена с судьбой и духовной биографией писателя" 12

Tvůrčí odkaz spisovatele Viktora Astafjeva je poselstvím zaníceného humanismu, poselstvím o velikosti člověka, o věčnosti prírody a o nekonečnosti vesmíru. Toto jeho dědictví žije a promlouvá $\mathrm{k}$ dnešku obzvláště naléhavě.

Cílem tohoto pojednání bylo představit prozaickou tvorbu Viktora Astafjeva, která byla pro svoje novátorství, neobyčejnost, nevšednost a jedinečnou svébytnost mnohdy opomíjena, přehližena a nedoceňována. Ale žádná výrazná a kvalitní umělecká hodnota

10 ČŽEN, J.: Svetjaščijesja zatjosi. Literaturnaja gazeta, No 17, 30 aprelja - 6 maja 2014 g., s. 4 .

11 MAKAROV, A. N.: Vo glubine Rossiji. Moskva:Sovremennik, 1973, s. 278.

12 CHVATOV, A. I.: Na rodnoj zemle, v rodnoj literature. Moskva: Sovremennik, 1980, s. 308. 
se v dějinách umění nemůže ztratit a zaniknout, protože všechno získá dříve či později své opodstatněné místo. A tak je určitá naděje a jistá perspektiva, že i Astafjevova díla budou i nadále objevována a začnou intenzivněji rezonovat s časem i dobou.

\section{Literatura:}

ASTAF'JEV, V. P.: Pereval. In: Sobranije sočinenij v četyrjoch tomach. Moskva: Molodaja gvardija, 1979, tom 1, s. 48 .

ASTAF'JEV, V.P.: Poslednij poklon. In: Sobranije sočinenij v četyrech tomach. Moskva: Molodaja gvardija, 1980, tom 1.

ASTAF'JEV, V.P.: Sobranije sočinenij v 4-ch t. Moskva: Molodaja gvardija, 1980.

BARUZDIN, S.: Neobchodimost' Astafjeva. Bibliografičeskij ukazatel': Viktor Petrovič Astaf jev. Sost. A. Pantelejeva, Krasnojarsk: Izdatel'stvo Krasnojarskogo universiteta, 1989, S. 5-27.

BEKEDIN, P.: fazyk vo rtu mjagok. Sovetskaja Rossija, 13 ijulja 1995, s. 2.

BELIKOV, J. A.: Duel' dlinoju v žizň. Literaturnaja gazeta, No 17, 30 aprelja - 6 maja 2014 g., s. 4 .

ČŽEN, J.: Svetjaščijesja zatjosi. Literaturnaja gazeta, No 17, 30 aprelja - 6 maja 2014 g., S. 4 .

CHVATOV, A. I.: Na rodnoj zemle, v rodnoj literature. Moskva: Sovremennik, 1980.

CHVATOV, F. I.: Živyje stranicy, pamjatnyje imena. Moskva: Sovremennik, 1989.

JANOVSKIJ, N.: Pisateli Sibiri. Izbrannyje stat'ji. Moskva: Sovremennik, 1988.

JANOVSKIJ, N.: Viktor Astafjev. Moskva: Sovetskij pisatel', 1982.

JUDALEVIČ, B. M.: Rasskaz v proze Viktora Astafjeva. Razvitije povestvovatel'nych žanrov v literature Sibiri. Novosibirsk: Nauka, 1980, s. 143-163.

KASACK, W.: Slovník ruské literatury 2o. století. Praha:Votobia, 2000.

KRAMARSKA, D.: Russkaja derevenskaja proza vtoroj poloviny XX veka. Litteraria

Sedlcensia. Redaktor naukowy Danuta Szymonik. Volumen IX, Colloquia, Studia Minora. Wydawnictwo IKR[i]BL, Siedlce 2015.

LANŠČIKOV, A. P.: Viktor Astafjev. Moskva: Sovetskaja Rossija, 1975.

MAKAROV, A. N.: Vo glubine Rossiji. Moskva:Sovremennik, 1973.

MATHAUSER, Z.: Estetika racionálního zření. Praha: Karolinum, 1999.

PARTHÉ, K. F.: Russian Village Prose. The Radiant Past. Princeton University Press. Princeton, New York, 1992.

PODJUKOV, I. A.: Esstetika narodnoj reči v poètike V. P. Astafjeva. Astafjevskije čtenija (17-18 maja 2002 g.). Perm', 2003, s. 7-14. 
POSPÍŠIL, I.: Ruská sovětská vesnická próza: jeden úhel pohledu. Novaja rusistika, 2016, roč. 9, č. 1, s. 71-74.

POSPÍŠIL, I.: Ruský román znovu navštívený. Historie, uzlové body vývoje, teorie a mezinárodní souvislosti: Od počátkủ $k$ výhledu do současnosti. Brno: Nadace Universitas: Cerm: Nauma, 2005.

RAZUVALOVA, A. I.: Pisateli-«derevenščiki»: literatura i konservativnaja ideologija 1970-ch godov. Litagent «NLO» - Novoje literaturnoje obozrenije», Moskva 2015. <https://libking.ru/books/sci-/sci-linguistic/566933-51-anna-razuvalova-pisateliderevenshchiki-literatura-i-konservativnaya-ideologiya-1970-h-godov.html\#book>. [online]. [cit. 28. 3. 2021].

SAVVATEJEVA, N.: Potrebnost' delat' dobro. Vzgljad pisatelja-frontovika Viktora Astafjeva iz prošlogo v buduščeje (zapis. N. Savvatejeva). Literaturnaja gazeta, No 19, 13-19 maja 2020 g., s. 7.

ZALYGIN, S.: Svoje slovo. In: ZALYGIN, S.: Literaturnyje zaboty. Moskva: Sovetskaja Rossija, 1982, s. 230-236.

\section{About the author}

\section{Zdeňka Matyušová}

University of South Bohemia in České Budějovice, Faculty of Education, Department of Slavic Languages and Literatures, Department of Russian Language and Literature, České Budějovice, Czech Republic

matyus@pf.jcu.cz

https://orcid.org/0000-0002-4139-8479

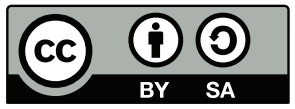

Toto dílo lze užít v souladu s licenčními podmínkami Creative Commons BY-SA 4.0 International («https:// creativecommons.org/licenses/by-sa/4.0/legalcode>). Uvedené se nevztahuje na díla či prvky (např. obrazovou či fotografickou dokumentaci), které jsou v díle užity na základě smluvní licence nebo výjimky či omezení př́slušných práv. 